\title{
EFEKTIVITAS STRATEGI DINAS KEBUDAYAAN DAN PARIWISATA KOTA PARIAMAN TERHADAP KEPUASAN PENGUNJUNG DI PANTAI GANDORIAH
}

\section{EFFECTIVENESS OF CULTURAL AND TOURISM DEPARTMENT OF STRATEGY OF CITY OF PARIAMAN ON SATISFACTIONVISITORS IN GANDORIAH BEACH}

\author{
Mesa Widya Maharani; Aldri Frinaldi ; Adil Mubarak \\ Jurusan Ilmu administrasu Publik \\ Fakultas Ilmu Sosial, Universitas Negeri Padang \\ Email : mesawidya@gmail.com
}

\begin{abstract}
Abstrak.
Penelitian ini bertujuan untuk mengetahui efektivitas strategi Dinas Kebudayaan dan Pariwisata Kota Pariaman terhadap kepuasan pengunjung di Pantai Gandoriah. Latar belakang penelitian ini adalah karena ditemukannya permasalahan-permasalahan pada efektivitas strategi yang kurang baik terhadap kepuasan pengunjung di Pantai Gandoriah. Rumusan masalah penelitian ini adalah apakah efektif strategi Dinas Kebudayaan dan Pariwisata Kota Pariaman terhadap kepuasan pengunjung di Pantai Gandoriah. Jenis penelitian ini adalah penelitian kuantitatif. Populasi penelitian ini adalah pengunjung yang berwisata ke Pantai Gandoriah. Pengambilan sampel yaitu dengan menggunakan rumus Slovin dan teknik pengambilan sampel pada penelitian ini yaitu Simple Random Sampling. Sampel dalam penelitian ini berjumlah 255 orang. Pengumpulan data dilakukan menggunakan angket dan pengukuran skala likert serta didukung studi dokumentasi. Data dianalisis menggunakan statistik deskriptif menggunakan bantuan software SPSS versi 16. Hasil penelitian menunjukkan bahwa efektivitas strategi Dinas Kebudayaan dan Pariwisata Kota Pariaman terhadap kepuasan pengunjung di Pantai Gandoriah dengan nilai efektivitas 71.67 yang berada pada rentang nilai 60-79,99 dan dinyatakan cukup efektif. Sementara kepuasan pengujung di Pantai Gandoriah pada efektivitas strategi Dinas Kebudayaan dan Pariwisata Kota Pariaman berada dalam kategori sedang karena berada pada rentang 41\%-60\% yaitu sebanyak 143 responden 56,1 \% dari 255 responden menyatakan bahwa kepuasan pengunjung dalam kategori cukup/sedang.
\end{abstract}

Kata Kunci : efektivitas strategi, kepuasan pengunjung, pariwisata

\section{Abstract}

This study aims to determine the effectiveness of the Pariaman City Culture and 
Tourism Office's strategy on visitor satisfaction at Gandoriah Beach. The background of this research is because of the finding of problems on the effectiveness of strategies that are not good for visitor satisfaction at Gandoriah Beach. The formulation of the problem of this research is 1) Is the effective strategy of the Culture and Tourism Office of Kota Pariaman on visitor satisfaction at Gandoriah Beach. This type of research is quantitative research. The population of this study were visitors who traveled to Gandoriah Beach. Sampling is by using the Slovin formula and the sampling technique in this study is Simple Random Sampling. The sample in this study amounted to 255 people. Data collection was carried out using questionnaires and likert scale measurements and supported by documentation studies. Data were analyzed using descriptive statistics using the help of SPSS version 16. The results showed that the effectiveness of the Pariaman City Culture and Tourism Office's strategy on visitor satisfaction at Gandoriah Beach was 71.67 which was in the range of 6079.99 and declared quite effective. While the final satisfaction in Gandoriah Beach on the effectiveness of the Pariaman City Culture and Tourism Service strategy is in the medium category because it is in the range of $41 \%-60 \%$, as many as 143 respondents $56.1 \%$ of 255 respondents stated that visitor satisfaction is in the moderate / moderate category.

Keywords: strategy effectiveness, visitor satisfaction, tourism

\section{A. Pendahuluan}

Kepariwisataan adalah keseluruhan kegiatan yang terkait dengan pariwisata dan bersifat multidimensi serta multidisiplin yang muncul sebagai wujud kebutuhan setiap orang dan negara serta interaksi antara wisatawan dan masyarakat setempat, sesama wisatawan, pemerintah, pemerintah daerah, dan pengusaha. Sumatera Barat memiliki daratan seluas 42.296,30 km 2 . Sumatera Barat kaya akan sumber keanekaragaman hayati dan keindahan alamnya mulai dari alam bebas, satwa liar, pulau, hutan hujan tropis, hingga pantainya. Kota Pariaman sebagai salah satu destinasi wisata di Indonesia yang terletak dipantai Barat Pulau
Sumatera, mempunyai potensi yang cukup besar terutama di bidang kepariwisataan dan kelautan.

Pariaman merupakan salah satu dari 19 kota dan kabupaten di Provinsi Sumatera Barat Indonesia. Kota Pariaman menawarkan pilihan wisata bahari yang banyak, kita bisa menyusuri pantai berpasir putih dengan pohon pinus dan angin laut dari Samudera Hindia yang nyaman. Sesuai yang tertuang dalam visi Renstra (Rencana Strategis) Dinas Pariwisata dan Kebudayaan kota Pariaman tahun 2013-2018 "Dengan Semangat Sabiduak Sadayuang Kita Wujudkan Kota Pariaman Menjadi 
Daerah Tujuan Wisata Pantai dan Bahari Dengan Mempertahankan Nilai-Nilai Agama dan Budaya" yang mana misinya yaitu meningkatkan ketersediaan sarana dan prasarana pariwisata, meningkatkan kualitas SDM pariwisata, meningkatkan dan mengembangkan intensifikasi dan ektensifikasi promosi produk wisata dan juga revitalisasi nilai-nilai agama dan budaya.

Efektivitas strategi yaitu tercapainya tujuan yang telah ditetapkan dari caracara atau suatu pola kegiatan terencana secara menyeluruh dalam jangka waktu tertentu. Munurut Sondang P Siagian dalam Pradikta (2014:6) indikator efektivitas yaitu, 1) tersedianya sarana dan prasarana, 2) sistim pengawasan dan pengendalian yang bersifat mendidik, 3) pelaksanaan tugas secara efektif dan efisien. Dari tiga indikator efektivitas strategi yang digunakan oleh pengunjung Pantai Gandoriah dalam memberikan penilaian efektivitas strategi tersebut maka akan membentuk rasa puas atau rasa tidak puas pengunjung terhadap strategi yang telah ditetapkan oleh Dinas Kebudayaan dan Pariwisata Kota Pariaman.

Berdasarkan wawancara peneliti dengan salah satu pegawai Dinas Kebudayaan dan Pariwisata Kota Pariaman Bidang Destinasi Pengembangan SDM, Kerjasama dan, Investasi Wisata mengatakan bahwa tempat sampah di kawasan sekitar pantai Gandoriah sudah banyak dalam keadaan yang rusak karena terbuat dari bahan plastik dan belum ada penanganan langsung terkait pengadaan tempat sampah baru oleh Organisasi Perangkat Daerah (OPD) yang bersangkutan. Salah satu pulau yang paling banyak diminati oleh wisatawan yaitu pulau Angso Duo. Pulau ini dapat dicapai dalam waktu 15 menit, dengan menggunakan perahu atau speedboat namun pada kenyataannya masih kurangnya standar keamanan dan kenyamanan bagi pengunjung yang ingin menggunakan jasa kapal penyeberangan ke pulau termasuk standar kelayakan kapal, pelabuhan, dan lain-lain. Pengunjung atau wisatawan yang hendak berwisata ke pulau namun tidak menggunakan rompi saat berada di atas kapal penyeberangan hal ini terjadi karena kurang tersedianya rompi apung, pelampung donat dan standar keamanan lainnya.

Masalah lain terkait kurangnya pengawasaan pelaksanaan dari strategi Dinas Kebudayaan dan Pariwisata Kota Pariaman dalam hal ini yaitu masih adanya petugas parkir yang belum memberikan tiket karcis kepada para pengendara dan masih banyak nya ditemui petugas parkir yang menetapkan biaya parkir melebihi standar yang telah ditetapkan. Masih banyaknya kapal penyeberangan tidak resmi yang dioperasikan oleh 
masyarakat sekitar yang mana kapal yang dioperasikan oleh masyarakat masih belum memiliki standar keamanan dan kelayakan kapal. Juga masih adanya para Anak Buah Kapal (ABK) yang menaikkan penumpang di Pantai Gandoriah yang seharusnya dilakukan di dermaga. Pelaksanaan tugas secara efektif dan efisien penulis melihat bahwa kurang efektif dan efisiennya terhadap tiket karcis karena Dinas Kebudayaan dan Pariwisata Kota Pariaman telah menetapkan standar penggunaan tiket karcis tetapi petugas parkir masih lalai dalam memberikan tiket kepada pengunjung seperti pengunjung telah membayar parkir tetapi tiket karcis tidak diberikan atau harga tiket karcis yang harganya tidak sesuai seperti yang semestinya.

Berdasarkan permasalahan tersebut peneliti tertarik untuk menganalisis Efektivitas Strategi Dinas Kebudayaan dan Pariwisata Kota Pariaman Terhadap Kepuasan Pengunjung di Pantai Gandoriah.

Tinjauan pustaka yang penulis gunakan ada beberapa variabel dan konsep. Pertama mengenai efektivitas, kata efektif berasal dari Bahasa Inggris effective artinya berhasil, sesuatu yang dilakukan dengan baik. Menurut Robbins dalam Pabundu Tika (2010:129) mendefenisikan efektivitas sebagai tingkat pencapaian organisasi jangka pendek dan jangka panjang. Menurut Kurniawan (2005:109) efektivitas berarti kemampuan melaksanakan tugas, fungsi (operasi kegiatan program atau misi) daripada suatu organisasi atau sejenisnya yang tidak adanya tekanan atau ketegangan diantara pelaksananya. Untuk menilai tingkat efektivitas dapat dinilai dengan melihat kesesuaian antara rencana awal dengan hasil kenyataan yang ada. Semakin efektif apabila hasil yang ada sesuai dengan rencana awal. Begitu pula sebaliknya apabila hasil yang tidak sesuai dengan rencana awal, maka dapat dikatakan bahwa tingkat efektifnya rendah. Kemudian menurut Steers dalam Sutrisno (2010:123), pada umumnya efektivitas hanya dikaitkan dengan tujuan organisasi, yaitu laba yang cenderung mengabaikan aspek penting dari seluruh prosesnya yaitu sumber daya manusia. Dari beberapa pendapat ahli tersebut dapat disimpulkan bahwa efektivitas adalah tujuan dari suatu organisasi yang dapat diartikan saat jika organisasi dapat mencapai tujuan yang telah ditentukan maka dapat dikatakan organisasi tersebut telah mencapai efektivitas.

Selanjutnya mengenai strategi menurut Chandler dalam Solihin (2012:64) merupakan "The determination of long term goals of an enterprise and the adoption of courses of action and the allocation of resources necessary for carrying out these goals" (Penentuan tujuan jangka panjang dari suatu perusahaan dan penerapan tindakan-tindakan dan alokasi sumber daya yang diperlukan 
untuk melaksanakan tujuan-tujuan ini). Pengertian strategi menurut Hamel dan Prahalad dalam Umar (2003) mendefenisikan strategi merupakan suatu tindakan yang bersifat terus menerus serta dilakukan berdasarkan sudut pandang tentang apa yang diharapkan oleh para pelanggan dimasa akan datang. Kemudian menurut Warsito (2006) menyatakan bahwa strategi ialah suatu pendekatan, atau pola kegiatan yang terencana untuk mencapai tujuan yang difokuskan pada a few key or critical areas atau secara sederhana dapat dikatakan bahwa strategi merupakan suatu pilihan tindakan yang betulbetul mampu menyelesaikan masalah yang dihadapi. Dari berbagai pengertian strategi di atas maka dapat ditarik kesimpulan bahwa strategi merupakan suatu cara-cara atau metode yang digunakan oleh suatu organisasi untuk mencapai tujuan yang diinginkan dalam jangka waktu yang telah ditentukan. Jadi dapat disimpulkan bahwa efektivitas strategi yaitu tercapainya tujuan yang telah ditetapkan dari cara-cara atau suatu pola kegiatan terencana secara menyeluruh dalam jangka waktu tertentu. Sondang P. Siagian dalam Pradikta (2014:6) menjelaskan suatu program/kebijakan dapat dikatakan efektif dengan unsur-unsur sebagai berikut, yaitu :

1) Tersedianya sarana dan prasarana, salah satu indikator efektivitas organisasi yaitu kemamapuan bekerja secara produktif. Dengan sarana dan prasarana yang tersedia dan mungkin disediakan oleh organisasi.

2) Sistem pengawasan dan pengendalian yang bersifat mendidik.

3) Pelaksanaan tugas secara efektif dan efisien, baiknya suatu program jika tidak dilaksanakan secara efektif dan efisien maka organisasi tersebut tidak akan mencapai sasarannya, karena dengan pelaksanaan organisasi semakin didekatkan pada tujuannya.

Mengenai kepuasan dalam bahasa inggris disebut satisfaction. Kata satisfaction berasal dari bahasa latin "satis" dan "facio". Satis berarti memadai, sedangkan facio berarti membuat. Jadi, kepuasan dapat diartikan bahwa membuat sesuatu memadai atau usaha memenuhi sesuatu menjadi memadai. Selain itu juga didefinisikan sebagai perasaan yang baik dimiliki seseorang ketika mendapatkan sesuatu atau yang diinginkan terjadi maka terjadilah kepuasan (Dasman Lanin dan Adil Mubarak 2010:118). Pengertian kepuasan menurut Gibson, dkk dalam Harbani Pasolong (2010:144) menyatakan bahwa kepuasan pada hakikatnya berkaitan dengan faktor kebutuhan seseorang (pelanggan), jika kebutuhan seseorang terpenuhi maka orang tersebut merasa puas, demikian pula sebaliknya. Aldri Frinaldi dan Muhamad Ali Embi (2012) mengemukakan berkaitan dengan 
kepuasan atau ketidakpuasan konsumen atau klien dapat diukur dengan tanggapan positif atau negatif mereka tentang layanan yang mereka terima, sehingga menciptakan tanggapan kepuasan atau ketidakpuasan. Dengan demikian, kepuasan atau ketidakpuasan di kalangan masyarakat/publik dapat pula dinilai /dilihat dari perasaan yang digambarkan seperti kesenangan, kebahagiaan, dan kasih sayang ketika puas, di sisi lain mereka akan terlihat kesal, cemberut atau cenderung memperlihatkan gelagat tertentu yang menunjukkan ketidakpuasan ketika mereka merasa tidak puas. indikator kepuasan pengunjung menurut Aldri dan Afriva (2017) yang terdiri dari :

1) Senang, dapat diartikan sebagai suatu perasaan puas/kepuaan seseorang setelah berwisata dimana semua beban dalam fikiran seseorang dapat hilang/ teratasi ketika berwisata dan menikmati keindahan objek wisata tersebut.

2) Bahagia, merupakan suatu perasaan atau keadaan pikiran yang ditandai dengan ketentraman seseorang ketika menikmati kawasan objek wisata tersebut.

3) Fasilitas yang ditemukan sesuai dengan harapan, ketersediaan sarana dan prasarana dan juga fasilitas pendukung dikawasan objek wisata yang lengkap dan memadai sesuai dengan apa yang diharapkan oleh pengunjung.

4) Ketersediaan informasi yang canggih dan modern, ini berarti informasi mengenai objek wisata yang disediakan telah dipromosikan dan melalui media cetak dan elektronik dan juga dapat diakses melalui website maupun media sosial.

5) Kinerja pelayanan, merupakan aparatur dan masyarakat pariwisata telah menyediakan pelayanan yang berkualitas, murah dan terjangkau bagi masyarakat juga merespon pertanyaan dan juga komplain yang diajukan mengenai objek wisata tersebut.

6) Harapan konsumen, yaitu perasaan puas dan tertarik untuk berkunjung kembali ke objek wisata tersebut karena aparatur dan masyarakat pariwisata telah menyediakan pelalayan pariwisata yang sesuai dengan yang diharapkan pengunjung wisata.

\section{B. Metode Penelitian}

Penelitian ini menggunakan metode kuantitatif dengan menggunakan analisis statistik. Lokasi penelitian ini akan dilaksanakan penulis di Pantai Gandoriah Kota Pariaman. Waktu penelitian ini bisa memekan waktu kurang lebih 1 bulan. Populasi dalam penelitian ini adalah pengunjung/wisatawan yang sedang atau pernah berkunjung di Pantai Gandoriah Kota Pariaman. Sampel dalam penelitian ini diseleksi menggunakan rumus slovin dengan tingkat kesalahan 5\% dan menghasilkan sebanyak 255 orang responden pengunjung di pantai 
Gandoriah. Pengambilan sampel

Kawin

dalam penelitian ini menggunakan

Belum Kawin 180

$70.5 \%$

teknik Simple Random Sampling.

Duda/Janda 5

Pengumpulan data mengunakan

Pendidikan Terakhir

angket yang diberikan kepada

SD

5

$2.0 \%$

pengunjung di pantai Gandoriah.

Pengukuran data menggunakan skala

SLTP

$2.0 \%$

SLTA

34

$13.3 \%$

likert. Data yang diperoleh kemudian

D3/S1

174

$68.2 \%$

dianalisis dengan menggunakan

Sumber: data diolah

standar sesuai dengan acuan Litbang Depdagri yaitu (a) Dibawah 40 berarti Sangat tidak efektif (b) 40-59,99 berarti Tidak efektif (c) 60-79,99 berarti Cukup efektif dan (d) Diatas 80 berarti Sangat efektif.

\section{Hasil dan Pembahasan}

\section{Karakteristik Responden}

Dalam penelitian ini responden berjumlah 255 orang pengunjung di Pantai Gandoriah, karakteristik responden dalam penelitian ini disajikan pada tabel berikut:

Tabel 1. Karekteristik Responden

\begin{tabular}{lll}
\hline \multicolumn{2}{l}{$\begin{array}{l}\text { Karakteristik } \\
\text { Persentase }\end{array}$} & Frekuensi \\
\hline \multicolumn{2}{l}{ Jenis Kelamin } \\
Laki-Laki & 71 & $27.8 \%$ \\
Perempuan & 184 & $72.2 \%$ \\
\hline Umur & & \\
< 18 Tahun & 55 & $21.6 \%$ \\
18-25 Tahun & 138 & $54.1 \%$ \\
26-35 Tahun & 25 & $9.8 \%$ \\
36-50 Tahun & 27 & $10.6 \%$ \\
>50 Tahun & 10 & $3.9 \%$ \\
\hline
\end{tabular}

\section{Status Perkawinan}

Dari tabel di atas dapat diketahui bahwa dari 255 responden, pengunjung pantai Gandoriah paling banyak berjenis kelamin perempuan sebanyak 184 orang dengan persentase $72.2 \%$. Usia responden paling banyak berkisar 18-25 tahun sebanyak 138 orang dengan persentase $54.1 \%$. Status perkawinan paling banyak yaitu belum kawin sebanyak 180 orang dengan persentase $70.5 \%$, dengan berpendidikan terakhir adalah SLTA sebanyak 174 orang dengan persentase $68.2 \%$.

\section{Deskripsi Efektivitas Strategi Dinas Kebudayaan dan Pariwisata Kota Pariaman Dalam Mencapai Keberhasilan Wisata di Pantai Gandoriah}

Gambaran efektivitas strategi Dinas Kebudayaan dan Pariwisata Kota Pariaman terhadap kepuasan pengunjung di Pantai Gandoriah melalui angket yang telah dibagikan kepada masyarakat yang menjadi responden pada penelitian ini. Dari angket tersebut diperoleh jawaban atas 7 item pernyataan mengenai efektivitas strategi Dinas Kebudayaan 
dan Pariwisata Kota Pariaman dalam mencapai keberhasilan wisata di Pantai Gandoriah, yang akan dijabarkan berikut ini:

Tabel 2. Efektivitas Strategi Dinas

Kebudayaan dan Pariwisata Kota Pariaman dalam Mencapai

Keberhasilan Wisata Pantai Gandoriah

\begin{tabular}{|l|l|c|c|c|}
\hline No & $\begin{array}{l}\text { Indikator } \\
\text { Variabel }\end{array}$ & TCR & N & $\begin{array}{c}\text { Kategori } \\
\text { Efektivitas }\end{array}$ \\
\hline 1 & $\begin{array}{l}\text { Sarana dan } \\
\text { Prasarana }\end{array}$ & 75.38 & 255 & $\begin{array}{l}\text { Cukup } \\
\text { Efektif }\end{array}$ \\
\hline 2 & Pengawasan & 72.75 & 255 & $\begin{array}{l}\text { Cukup } \\
\text { Efektif }\end{array}$ \\
\hline 3 & $\begin{array}{l}\text { Pelaksanaan } \\
\text { tugas secara } \\
\text { efektif dan } \\
\text { efisien }\end{array}$ & 66.87 & 255 & $\begin{array}{l}\text { Cukup } \\
\text { Efektif }\end{array}$ \\
\hline $\begin{array}{l}\text { Rata-rata } \\
\text { efektivitas } \\
\text { strategi }\end{array}$ & 71.67 & 255 & $\begin{array}{l}\text { Cukup } \\
\text { Efektif }\end{array}$ \\
\hline
\end{tabular}

Sumber: data diolah

Berdasarkan tabel di atas dapat dilihat bahwa nilai efektivitas untuk indikator sarana dan prasarana adalah 75.38 yang mana menurut Litbang Depdagri dalam Ni Luh Ayu Kartika Yuniastari (2015:563) berada pada rentang nilai 60-79,99 dikategorikan cukup efektif. Nilai efektivitas untuk indikator pengawasan adalah 72.75 yang mana menurut Litbang Depdagri dalam Ni Luh Ayu Kartika Yuniastari (2015:563) berada pada rentang nilai 60-79,99 dikategorikan cukup efektif. Dan nilai efektivitas untuk indikator pelaksanaan tugas secara efektif dan efisien yaitu 66.87 yang mana menurut Litbang Depdagri dalam Ni Luh Ayu Kartika Yuniastari
(2015:563) berada pada rentang nilai 60-79,99 dikategorikan cukup efektif.

\section{Deskripsi Variabel Kepuasan Pengunjung}

Hasil rata-rata skor variabel kepuasan pengungjung dan mean pada penelitian ini dapat dilihat pada tabel berikut:

Item Pernyataan

\section{Mean}

Puas setelah berwisata dan menikmati keindahan kawasan objek wisata ini $=$ 3.26

Semua beban dalam fikiran saya hilang ketika saya menikmati kawasan objek wisata ini $=3.25$

Bahagia setelah menikmati kawasan objek wisata ini $=3.25$

Mendapatkan ketentraman ketika menikmati kawasan objek wisata ini $=$ 3.16

Ketersediaan sarana dan prasarana di objek wisata ini seperti arena bermain lengkap sesuai dengan yang saya harapkan $=2.97$

Fasilitas pendukung yang disediakan seperti mushola, toilet, lahan parkir, dan kantin tersedia dengan lengkap dan memadai $=3.06$

Informasi mengenai objek wisata ini telah dapat diakses melalui website ataupun media sosial $=3.10$

Informasi objek wisata yang disediakan sesuai dengan keadaan sebenarnya $=3.00$

Pengelola objek wisata telah menyediakan pelayanan wisata yang berkualitas $=2.91$ 
Aparatur dan masyarakat pariwisata telah menyediakan pelayanan

wisata yang murah dan terjangkau bagi masyarakat $=3.09$

Petugas objek wisata telah merespon pertanyaan dan complain yang saya ajukan mengenai objek wisata ini = 2.85

Aparatur dan masyarakat pariwisata telah menyediakan pelayanan

pariwisata yang sesuai dengan harapan saya $=2.91$

Saya tertarik untuk berkunjung kembali karena kinerja pelayanan yang diberikan sesuai dengan apa yang saya harapkan $=3.20$

Rata-rata indikator kepuasan pengunjung $=3.07$

Berdasarkan data di atas dapat dilihat bahwa nilai mean indikator kepuasan dapat dikategorikan cukup tinggi dan nilai meannya adalah 3,07 karena mean yang berada diatas 3,07 sebanyak 143 responden atau 56,1\% dari 255 responden. Angka tersebut menunujukkan bahwa responden yang merasa puas setelah berwisata dan menikmati keindahan kawasan objek wisata di Pantai Gandoriah ini, ketersediaan sarana dan prasarana di objek wisata ini seperti arena bermain lengkap sesuai dengan yang pengunjung harapkan, fasilitas pendukung yang disediakan seperti mushola, toilet, lahan parkir, dan kantin tersedia dengan lengkap dan memadai, informasi mengenai objek wisata ini telah dapat diakses melalui website ataupun media sosial, informasi objek wisata yang disediakan sesuai dengan keadaan sebenarnya, aparatur dan masyarakat pariwisata telah menyediakan pelayanan wisata yang murah dan terjangkau bagi masyarakat, petugas objek wisata telah merespon pertanyaan dan komplain yang pengunjung ajukan mengenai objek wisata ini, aparatur dan masyarakat pariwisata telah menyediakan pelayanan pariwisata yang sesuai dengan harapan pengunjung dan pengunjung tertarik untuk berkunjung kembali karena kinerja pelayanan yang diberikan sesuai dengan apa yang pengunjung harapkan. Dengan demikian dapat dikatakan bahwa sebagian responden menilai bahwa aspek kepuasan berada dalam kategori cukup tinggi.

\section{Penutup}

Berdasarkan hasil penghitungan efektivitas strategi Dinas Kebudayaan dan Pariwisata Kota Pariaman terhadap kepuasan pengunjung di Pantai Gandoriah dan secara umum didapat hasil bahwa pelayanan yang dilakukan cukup efektif. Tingkat efektivitas strategi senilai 71.67 yang berada pada rentang nilai 60-79,99 dan dinyatakan cukup efektif. Hal ini berarti sarana dan prasarana, pengawasan, dan pelaksanaan tugas secara efektif dan efisien sudah cukup baik.

Sementara kepuasan pengunjung di pantai Gandoriah terhadap strategi 
Dinas Kebudayaan dan Pariwisata Kota Pariaman dapat dikategorikan cukup tinggi dan nilai meannya adalah 3,07 karena mean yang berada diatas 3,07 sebanyak 143 responden atau $56,1 \%$ dari 255 responden menyatakan bahwa efektivitas strategi sedang.

\section{Daftar Pustaka}

Harbani Pasolong. 2010. Teori Administrasi Publik. Bandung : Alfabeta

Kurniawan, Agung. (2005). Transformasi Pelayanan Publik . Jakarta : Grafindo Persada

Solihin, Ismail. (2012). Manajemen Strategik. Bandung : Erlangga

Sutrisno, Edy. (2010). Budaya Organisasi. Jakarta : Kencana

Tika, Pabundu. (2010). Budaya Organisasi dan Peningkatang Kinerja Perusahaan. Jakarta : Bumi Aksara.

Uhar Suharsaputra. 2012. Metode Penelitian (Kuantitatif, Kualitatif, dan Tindakan). Bandung: Refika Aditama

Umar, Husein. (2003). Strategic Management in Action. Jakarta : PT Gramedia Pustaka Utama

Warsito, Utomo. (2006). Administrasi Publik. Yogyakarta : Pustaka Pelajar

Renstra (Rencana Strategi) Dinas Pariwisata dan Kebudayaan kota Pariaman tahun 2013-2018

Aldri Frinaldi dan Muhamad Ali Embi. 2012. The Impact of Etnict Work Culture on Civil Servant Work Culture (a Case
Study of Work Culture Punctuality and Tranparency of Public Service in Pasaman Barat). Aldri Frinaldi dan Muhamad Ali Embi. Proceedings Public Service \& Utilities. ASPA Indonesia International Seminar and IAPA annual Conference 2012. ISBN 978-602-203-452-0. Universitas Brawijaya Press

Aldri Frinaldi dan Afriva Khaidir. 2017. Membangun Model Kebijakan Budaya Kerja Sadar Wisata di Kalangan Aparatur dan Masyarakat Pariwisata dalam Upaya Peningkatan Kepuasan Masyarakat Berkunjung ke Lokasi Wisata di Sumatera Barat. Laporan Hasil Penelitian Tahun pertama.Skim Penelitian Tim Pascasarjana. LP2M Universitas Negeri Padang. Padang.

Dasman Lanin dan Adil Mubarak. 2010. "Kepuasan Diskonfirmasi Warga pada Sektor Publik: Kasus Pelayanan Kebutuhan Dasar Pemerintahan Kota Padang Panjang". Jurnal Demokrasi. Vol 9, No 2

Ni Luh Ayu Kartika Yuniastari S, Ratna Kartika Wiyati. 2015. Pengukuran Tingkat Efektivitas dan Efesiensi Sistem Eresearch STIKOM Bali.Dalam ejournal Konferensi Nasional Sistem \& Informatika. Denpasar: STIKOM Bali 
Pradikta, Eggyawang Setia (2014)

Efektivitas Program E-

Performance Sebagai Upaya

Untuk Mewujudkan Peningkatan

Kinerja Dinas Kebersihan Dan

Pertamanan Kota Surabaya,

Jurnal Kebijakan Dan

Manajemen Publik, vol.2 no.1. 
Spirit Publik Volume 14, Nomor 1, April 2019

Halaman 69-80

P-ISSN. 1907-0489 E-ISSN 2580-3875 